\title{
Amentoflavone Acts as a Radioprotector for Irradiated v79 Cells by Regulating Reactive Oxygen Species (ROS), Cell Cycle and Mitochondrial Mass
}

\author{
Ping Xu ${ }^{1 \&}$, En-Jin Jiang ${ }^{2 \&}$, Si-Yuan Wen ${ }^{2 *}$, Dan-Dan $\mathrm{Lu}^{2}$
}

\begin{abstract}
Radioprotective effects of amentoflavone were investigated by examining cell viability, apoptosis, cell cycling concentrations of intracellular ROS (reactive oxygen species), and relative mitochondrial mass by flow cytometry after ${ }^{60} \mathrm{Co}$ irradiation. Pretreatment with amentoflavone 24 hours prior to $8 \mathrm{~Gy}{ }^{60} \mathrm{Co} \gamma$-ray irradiation significantly inhibited apoptosis, promoted the G2 phase, decreased the concentration of ROS and mitochondrial mass. These results collectively indicate that amentoflavone is an effective radioprotective agent.
\end{abstract}

Keywords: Amentoflavone - radioprotector - ROS - mitochondrial mass - cell cycle

Asian Pac J Cancer Prev, 15 (18), 7521-7526

\section{Introduction}

Ionizing radiation generates reactive oxygen species (ROS) in exposed cells. These free radicals can induce damage to critical macromolecules such as nucleic acids, proteins, lipids and carbohydrates in the plasma and organelle membranes. The DNA damage can induce cell cycle delay or apoptosis (Shimoi et al., 1996; Rao et al., 2006; Li et al., 2007). In humans, it is important to protect biological systems from radiation-induced peroxide toxicity ( Sweet and Singh, 1999; Schmidt-Ullrich et al., 2000;Bernd and Rainer, 2002).

Ionizing radiation that induces mitochondrial membrane damage can cause mitochondrial dysfunction, which not only reduces the cell's energy supply, but also triggers the mitochondrial membrane potential. Increased mitochondrial membrane permeability will decrease the release of cytochrome $\mathrm{C}$, which could induce signaling pathways that lead toward cell apoptosis, so mitochondria play an important and central role in apoptosis (Eric et al., 1995; Zhang et al., 2000; Nugent et al., 2007). A high concentration of ROS is not only toxic to the cell but also acts as a molecular signal to up-regulate the expression of Bax protein. Bax-Bak complex formation will result in increased mitochondrial membrane permeability and mitochondrial swelling, which will rupture the outer mitochondrial membrane, leaving a lack of energy supply for the cell which ultimately results in cell apoptosis (Deng et al., 2003). Thus maintaining mitochondrial membrane stability reduced apoptosis. The radiation-induced cell membrane permeability stimulates cell cycle arrest in the G2 phase, and ultimately leads to apoptosis (Reipert et al.,
1995; Weiss and Landauer, 2000; Weiss and Landauer, 2003; Johannes and Jan, 2004).

Since ROS are prevalent in the pathogenesis of several diseases, as a signal transduction with an important role in initiating cell apoptosis, removal of ROS is a widely accepted mechanism of radiation protection. Therefore, as antioxidants can reduce the generation of reactive oxygen species after the adverse effects of radiation, it is feasible to develop a radiation protection agent using nontoxic antioxidants (Jurgensmeier et al., 1998; Spodnik et al., 2002; Limoli et al., 2003; Lee et al., 2005; Wu et al., 2005).

Flavonoids are naturally-occurring compounds present in a variety of fruits, vegetables and seeds, and in Chinese herbal medicines (Ross and Kasum, 2002; Beecher, 2003) They have many biological properties including antioxidative, anti-inflammatory and antifungal effects. Growing lines of evidence have demonstrated that flavonoids are neuroprotective in a variety of cellular and animal models of neurodegenerative diseases, primarily due to their antioxidative properties (Dajas et al., 2003; Mandel et al., 2004; Simonyi et al., 2005; Zhao, 2005). However, the antitumor capacity of flavonoids has not been extensively evaluated, and their mechanisms of action are not wellelucidated.

Amentoflavone, 8- (5- (5, 7-dihydroxy-4-oxo4Hchromen-2-yl) -2 -hydroxyphe-nyl)-5, 7-dihydroxy-2(4-hydroxyphenyl) -4H-chromen-4-one, belonging to the biflavonoid class of flavonoids, is abundant in Selaginella tamariscina and has been used for the treatment of cancer in traditional Chinese medicine. It has also been used as an antioxidant, vasorelaxant, anti-HIV and anti-angiogenic 
agent (Mora et al., 1990; Lin et al., 1997; Kang et al., 2004; Guruvayoorappan and Kuttan, 2008). The structure of amentoflavone is given in Figure 1. Nonetheless, to our knowledge there have been no reports on the radioprotective effects of amentoflavone on apoptosis, which plays an important role in v79 cell death. This study investigated the molecular mechanism of its function as a radioprotector.

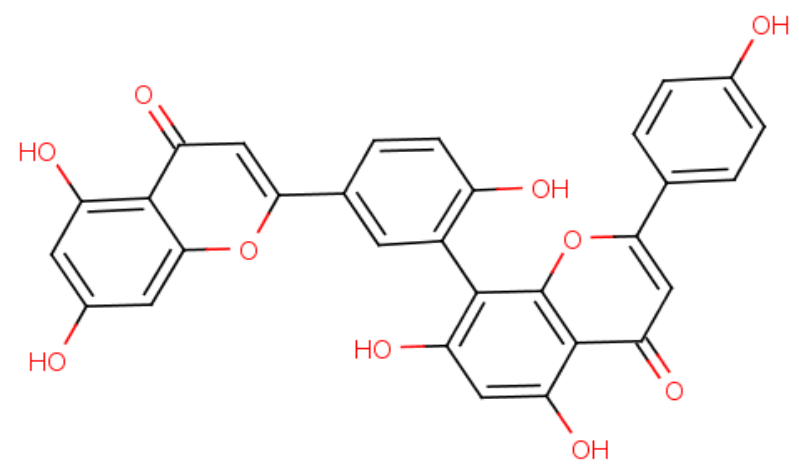

Figure 1. Structure of AMF

\section{Materials and Methods}

\section{Reagents and instruments}

Cell counting kit-8 (CCK-8) was manufactured by Dojindo Laboratories (Kumamoto, Japan). Apoptosis kit (Baosai Biotechnology Co., Ltd, Beijing, China). Cell cycle, ROS, mitochondrial mass detection reagents (Biyun-tian Biotechnology, Beijing, China). DMEM cell culture medium, fetal calf serum (Gibco BRL). Model 680 multi-functional microplate reader (BIO-RAD). Flow sorter(BD). Amentoflavone was purchased from the Chinese National Institute for Control of Pharmaceutical and Biological Products (Beijing, China).

\section{Cell culture}

V79 Chinese hamster lung fibroblast cells were cultured adherently in DMEM medium containing $10 \%$ fetal bovine serum, $100 \mathrm{U} / \mathrm{mL}$ penicillin and $100 \mathrm{U} / \mathrm{mL}$ streptomycin at $37^{\circ} \mathrm{C}$ in a humidified atmosphere of $5 \%$ $\mathrm{CO} 2$. The culture medium was replaced every 48 hours.

\section{Cell viability}

V79 cells $\left(1 \times 10^{5}\right.$ cells $\left./ \mathrm{mL}\right)$ were seeded in 96 well plates in the logarithmic growth phase. After 24 hours, cells were irradiated with 60Co $\gamma$-ray at a dose rate of 227.9 c Gy/min, 4-12 Gy. A CCK-8 solution (10 $\mu \mathrm{L} /$ well) was added 12-96 hours after irradiation. The absorbance of each well at $490 \mathrm{~nm}$ was determined after a further 4 hours, using a multi-functional microplate reader. Cell viability $\%=$ experimental group/control group $\times 100 \%$.

Cells were pretreated with $1-12 \mu \mathrm{g} / \mathrm{mL}$ amentoflavone to screen for a safe dose, and cell viability was determined after 12-96 hours.

\section{Detection of apoptosis, cell cycle, mitochondrial mass, ROS}

v79 cells $\left(1 \times 10^{6}\right.$ cells $\left./ \mathrm{mL}\right)$ were seeded in 6 -well plates and cultured for 24 hours with $3-7 \mu \mathrm{g} / \mathrm{mL}$ of amentoflavone (final concentration) in a DMEM solution. Cells were irradiated with an 8 Gy 60Co $\gamma$-ray after 24 hours of incubation with the drug. Forty-eight hours after the cells were irradiated, cells from the normal group, the irradiation group and the drug group were collected and centrifuged at $1000 \mathrm{r} /$ minute for 10 minutes. This step prepared the cells for the following assays that detected apoptosis, cell cycle mitochondrial mass, ROS.

Detection of apoptosis The supernatant was washed with cold PBS 2 times and suspended in $200 \mu \mathrm{L}$ Binding Buffer. Ten microliters of Annexin V-FITC was added and the supernatant was gently shaken at room temperature away from light for 15 minutes. Then $300 \mu \mathrm{L}$ Binding Buffer and $5 \mu \mathrm{L}$ propidium iodide (PI) was added, and the samples were analyzed by flow cytometry to detect apoptosis.

Cell cycle analysis Pelleted cells were washed twice with fresh PBS, centrifuged to remove PBS liquid, pelleted again and then transferred to a $2 \mathrm{~mL}$ eppendorf (EP) tube for staining. Then $0.5 \mathrm{~mL}$ of a propidium iodide staining solution was added to each tube, and tubes were incubated in the dark at $37^{\circ} \mathrm{C}$ for 30 minutes and then stored in the dark at $4^{\circ} \mathrm{C}$. Each sample was analyzed for cell cycle status using a $488 \mathrm{~nm}$ wavelength red fluorescence laser by flow cytometry.

Detection of Mitochondrial mass Mito-Tracker Green (1:50000 dilution) was added to fresh culture media to a final concentration of $20-200 \mathrm{~nm}$ and stored before its use in the dark at $37^{\circ} \mathrm{C}$. After cells were collected, the stain working solution was added and incubated for 15-45 minutes. After staining, the working solution was removed and fresh culture media was added for flow cytometry analysis of the mitochondrial mass.

Detection of ROS Cells were pelleted, washed twice with fresh PBS, centrifuged to remove the PBS liquid, pelleted again and then transferred to a $2 \mathrm{~mL}$ EP tube. A 1:1000 dilution of the probe DCFH-DA in serumfree media was loaded onto the cells. The samples were incubated in the dark at $37^{\circ} \mathrm{C}$ for 20 minutes, then washed with fresh cell culture media three times to remove the DCFH-DA, and then were analyzed by flow cytometry to determine the intracellular ROS concentration.

\section{Statistical analysis}

All quantitative measurements were expressed as means \pm standard deviation (SD). The data was analyzed using one-way analysis of variance (ANOVA) on SPSS/ PC* (statistical package for social sciences, personal computer) and the group means were compared by Duncan's Multiple Range Test (DMRT). The results were considered statistically signifi cant for $p<0.05$.

\section{Results}

Establishment of a cell model of radiation damage and determination of the doseage of amentoflavone administered to 179 cells

v79 cells were assayed for viability 48 hours after irradiation: a dose of 4 Gy $\gamma$-ray radiation failed to reach the half-lethal dose, a dose of $8 \mathrm{~Gy}$ radiation was halflethal, and a dose of 12 Gy radiation yielded cells that showed irreversible necrosis. Therefore, with a radiation intensity of $8 \mathrm{~Gy}$ the radiation-induced apoptosis between 
Amentoflavone Acts as a Radioprotector for 79 Cells by Regulating ROS, Cell Cycling and Mitochondrial Mass

24 and 48 hours was not yet significant. However, 72 hours may be too late to assess the radiation damage to cells when testing the maximum protective effect of amentoflavone because 48 hours after irradiation, the rate of apoptosis slows, thus making it difficult to detect significant changes. The cell toxicities of amentoflavone in v79 cells were tested. Amentoflavone concentrations over $12 \mu \mathrm{g} / \mathrm{mL}$ are toxic to cells, so amentoflavone was administered within a range of $1-8 \mu \mathrm{g} / \mathrm{mL}$ (Figure 2 ).

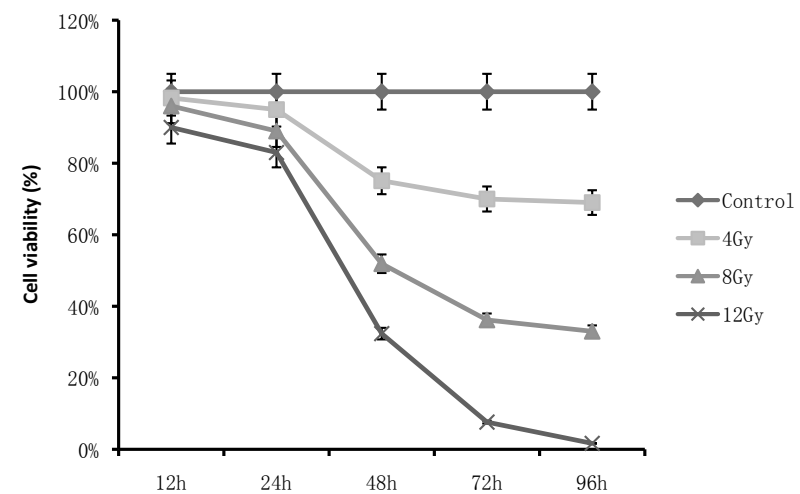

Figure 2. Cell Viability at 12, 24, 48, 72 and 96 hours after 4, 8, or 12 Gy Irradiation
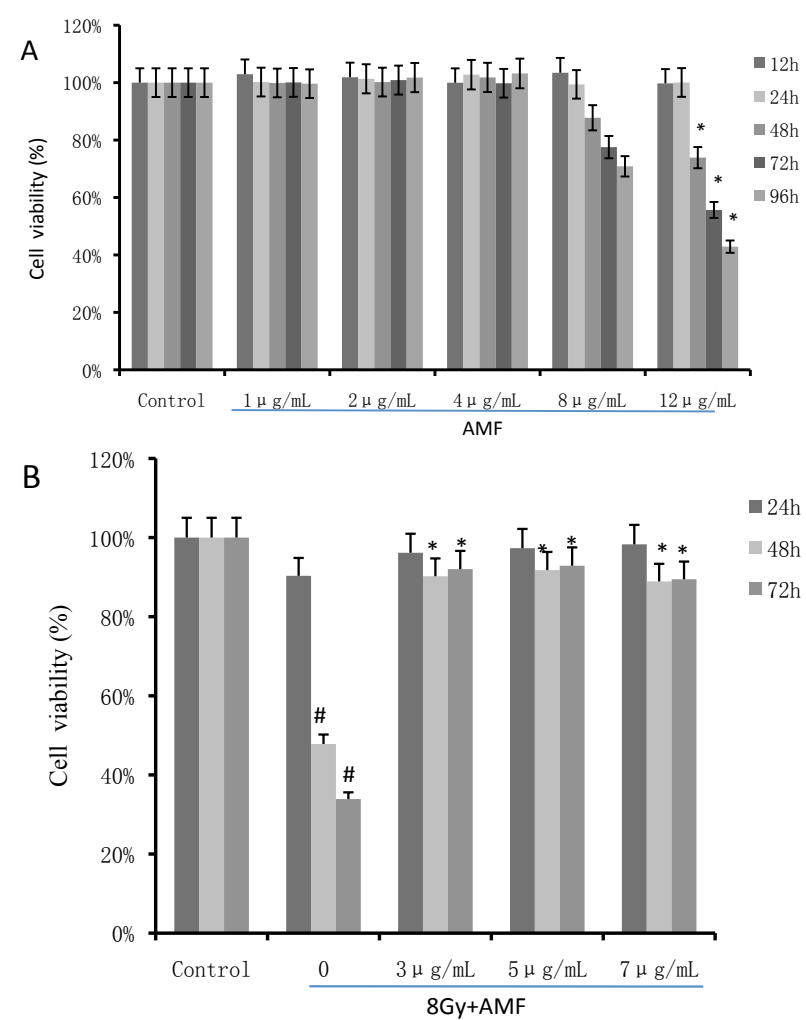

Figure 3. The Effect of Amentoflavone on RadiationInduced Cell Viability of V79; (A) Cells were treated with $1-12 \mu \mathrm{g} / \mathrm{mL}$ of amentoflavone, and cell viability was measured after 12-96 hours to ensure that the concentration of amentoflavone administrated to the v79 cells was not toxic. $(* p<0.01$, compared with normal group); (B) Pretreatment of v79 cells with 3, 5, or $7 \mu \mathrm{g} /$ $\mathrm{mL}$ of amentoflavone 24 hours before 8 Gy 60Co $\gamma$-ray irradiation can increase the cell viability as measured after 24, 48 and 72 hours. ( ${ }^{\#} p<0.01$, compared with normal group; *, $p<0.01$, compared with 8 Gy group)
As many kinds of injury could be assayed 48 hours after irradiation of cells, this model can serve as a cell model of radiation damage and be used to evaluate the radiation protection effect of amentoflavone. Based on our results, pretreatment of cells with amentoflavone of $3 \mu \mathrm{g} /$ $\mathrm{mL}, 5 \mu \mathrm{g} / \mathrm{mL}, 7 \mu \mathrm{g} / \mathrm{mL}$ increased the survival rate after 8 Gy $60 \mathrm{Co} \gamma$-ray radiation. (Figure 3).

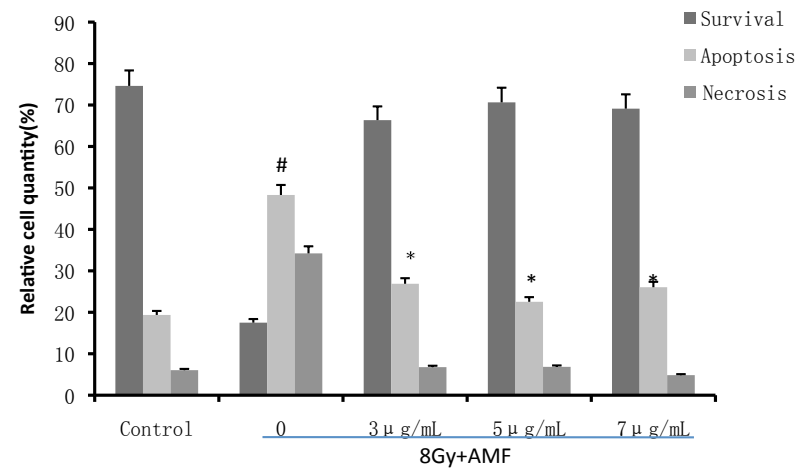

Figure 4. Amentoflavone Increased the Survival Rate of Cells after Exposure to Radiation. v79 cells were pretreated with or without various concentrations of $\operatorname{AMF}(3,5,7 \mu \mathrm{g} / \mathrm{mL})$ and were exposed to $8 \mathrm{~Gy}{ }^{60} \mathrm{Co}$ $\gamma$-ray radiation. The level of cell death in the samples was measured by flow cytometry and the percentages of necrosis cells were compared (\#, $\mathrm{P}<0.01$, compared with normal group; $* p<0.01$, compared with 8 Gy group
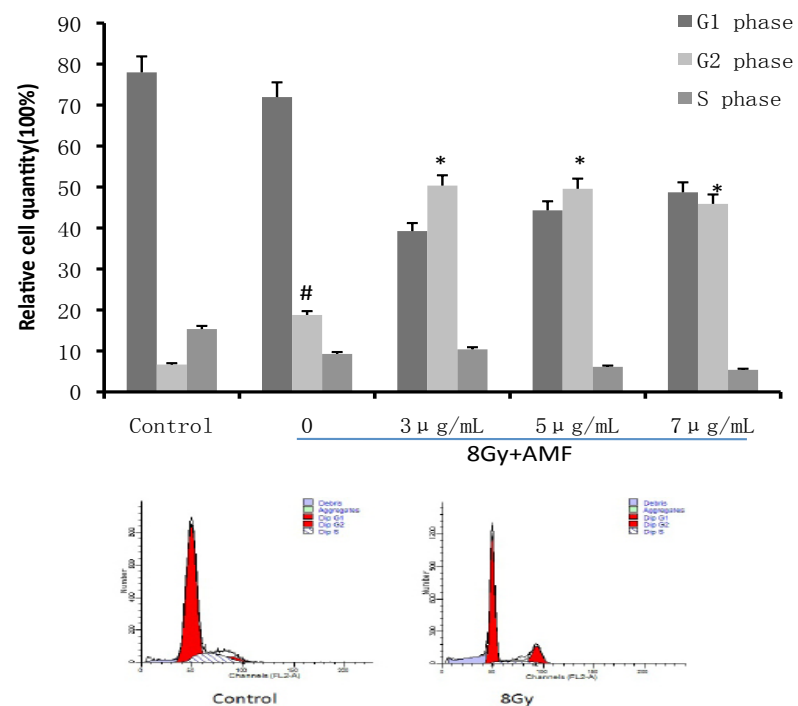

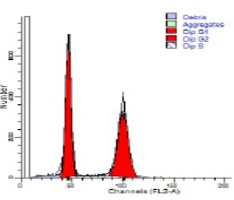

$8 G \mathrm{y}+3 \mu \mathrm{g} / \mathrm{mL}$
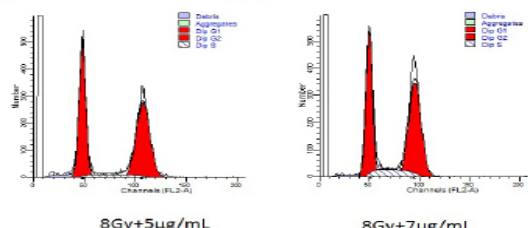

$8 G \mathrm{y}+7 \mu \mathrm{g} / \mathrm{mL}$
Figure 5. The Effect of Amentoflavone on Cell Cycle after Irradiation. v79 Cells were pretreated with or without various concentrations of $\operatorname{AMF}(3,5,7 \mu \mathrm{g}$ / $\mathrm{mL}$ ) and were exposed to $8 \mathrm{~Gy}{ }^{60} \mathrm{Co} \gamma$-ray radiation. Amentoflavone increased the G2 phase of the cell cycle after exposure to radiation. The percentages of cells in G2 were compared $\left({ }^{\#} P<0.05\right.$, compared with normal group; $* p<0.01$, compared with 8 Gy group) 


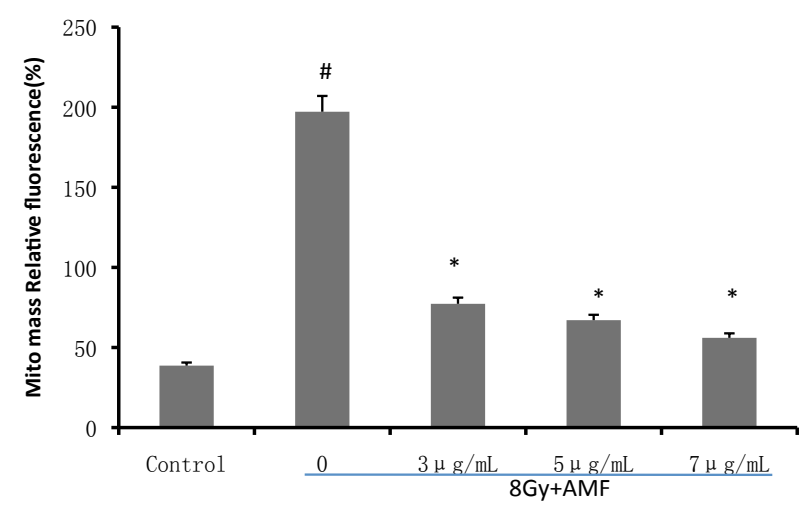

Figure 6. Inhibitory Effect of Amentoflavone on the Radiation-Induced Increase in Mitochondrial Mass. v79 cells were pretreated with or without various concentrations of $\operatorname{AMF}(3,5,7 \mu \mathrm{g} / \mathrm{mL})$ and were exposed to 8 Gy $60 \mathrm{Co} \gamma$-ray radiation. The level of cell death in the samples was measured by flow cytometry. The mitochondrial mass was compared $\left({ }^{\#} p<0.01\right.$, compared with the normal; ${ }^{*} p<0.01$ compared with the irradiation group).

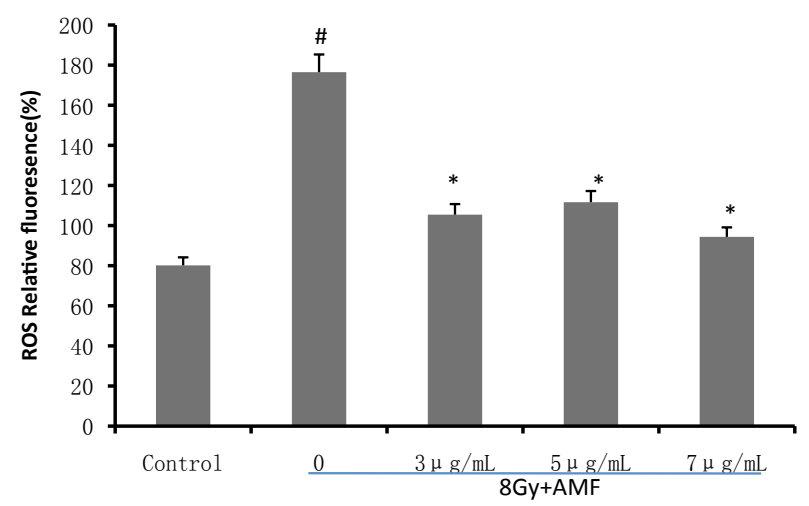

Figure 7. Inhibitory Effect of Amentoflavone on the Radiation-Induced Increase in ROS Concentration. v79 cells were pretreated with or without various concentrations of $\operatorname{AMF}(3,5,7 \mu \mathrm{g} / \mathrm{mL})$ and were exposed to $8 \mathrm{~Gy}{ }^{60} \mathrm{Co} \gamma$-ray radiation. The percentages of ROS cells were compared $\left({ }^{\#} p<0.01\right.$, compared with the normal; $* p<0.05$ compared with the irradiation group).

The phenotypic observations: effects on cell apoptosis, cell cycle and mitochondrial mass

The effects of different doses of amentoflavone on apoptosis were investigated. The apoptosis rates at 48 hours after irradiation are shown in Figure 3. Irradiation increased the apoptosis rate to $49 \%$, while pretreatment with amentoflavone of $3 \mu \mathrm{g} / \mathrm{mL}, 5 \mu \mathrm{g} / \mathrm{mL}, 7 \mu \mathrm{g} / \mathrm{mL}$ before $8 \mathrm{~Gy}$ irradiation significantly reduced the rate of apoptosis to $26 \%, 22 \%, 26 \%$. The results show that in the treatment group of amentoflavone significantly reduced cell death, and compared with the irradiation group, amentoflavone provides a radiation protection effect (Figure 4).

Radiation increased the ratio of cells in the $\mathrm{G} 2$ phase to $18.78 \%$ compared with the control group for $6.68 \%$. The groups treated with amentoflavone of $3 \mu \mathrm{g} / \mathrm{mL}, 5 \mu \mathrm{g} / \mathrm{mL}$, $7 \mu \mathrm{g} / \mathrm{mL}$ have more cells in the $\mathrm{G} 2$ phase than irradiation group for the ratio of $50.35 \%, 49.57 \%, 45.89 \%$ (Figure 5).

Radiation damage to the mitochondrial membrane changed the membrane permeability, causing the mitochondrial membrane to swell. Radiation increased the mitochondrial mass to $197.19 \%$ while amentoflavone of $3 \mu \mathrm{g} / \mathrm{mL}, 5 \mu \mathrm{g} / \mathrm{mL}, 7 \mu \mathrm{g} / \mathrm{mL}$ decreased it to $77.27 \%$, $67.07 \%, 56.03 \%$ (Figure 6).

\section{Effect on intracellular ROS}

Because radiation induced an increase in intracellular ROS, excessive oxidative damage caused cell necrosis and apoptosis. The administration of amentoflavone significantly decreased the concentration of ROS, with a drug concentration of $7 \mu \mathrm{g} / \mathrm{mL}$ giving the most significant effect. Reducing the ROS concentration in the cells was the most direct and effective way to radioprotect them (Figure 7).

\section{Discussion}

This investigation focused on the use of amentoflavone as a protector against radiation-induced apoptosis through the use of a v79 cell model (Xu et al., 2011). The v79 cell is a well-established model for studying radiation-induced damage of cells. The degree of injury to a cell will differ significantly depending on the radiation dose. After radiation, v79 cells reflect the accumulation of radiation damage well (Elena and Valeria 2004). Because the v79 cells can enter the cell cycle 2-3 times within 12-14 hours of entering the logarithmic growth phase, they can show to a significant degree the effect of ionizing radiation on DNA damage. $v 79$ cells were exposed to 8 Gy radiation and assayed $48 \mathrm{~h}$ after irradiation, at their half-lethal dose. Moreover, the v79 cell model of radiation damage has very good repeatability, with significant differences in injury sensitive to changes in radiation dose; thus v79 cells can serve as a good model for radiation-induced damage of cells. After irradiation, the ROS levels were higher than normal. Increased ROS levels lead to excessive oxidation of cellular macromolecules, cause mutations in the mitochondrial DNA, age the mitochondrial membrane and membrane organelles, and cause cell death.

The mitochondria are organelles that are extremely sensitive to damage; their pathological changes are reflected by a change in the mitochondrial mass, size, and structure. The general phenomenon induced by radiation is swelling of the mitochondria and mitochondrial membrane rupture (Boonstra and Post 2004; Mirjolet et al., 2000). Mitochondrial swelling is reflected by an increase in mitochondrial mass, which is commonly found in aging and early apoptotic cells. In this investigation, the mitochondrial mass after irradiation was significantly increased because radiation led to calcium overload in cells through calcium intake by the mitochondrial $\mathrm{Ca} 2+$ transporters (MCU). When the mitochondrial calcium intake reaches a certain level, the mitochondrial permeability transition pore (PTP) opens. The PTP is non-selective when the number of molecules from the cytoplasm to the mitochondria accumulates. After damage to and dysfunction of the mitochondrial membrane potential, permeabilization of the mitochondrial outer membrane leads to the release of cytochrome $\mathrm{C}$ from the mitochondrial intermembrane space into the cytoplasm 
Amentoflavone Acts as a Radioprotector for $v 79$ Cells by Regulating ROS, Cell Cycling and Mitochondrial Mass

(O’Reilly et al., 1996; Rosser et al., 2004; Gao et al., 2004). Cytochrome $\mathrm{C}$ is an important component in the apoptosis pathway: it initiates cell death.

The G2 phase occurs during the gap between DNA synthesis and mitosis and during this phase the cell will continue to grow. ROS may act as signaling molecules to the MAPK signaling pathway; the MAPKs are known to regulate the proliferation and apoptosis of cells. Therefore, an increase in ROS levels can retard the cells in the G2 phase, thus inhibiting cell proliferation (Linke et al., 1996; Bartek and Lukas, 2001; Vogler, et al., 2009).

v79 cells were treated with amentoflavone for $24 \mathrm{~h}$ before irradiation, which aided cells in scavenging the large volume of radiation-induced ROS, The mitochondrial mass in treated cells was significantly lower than in the group without amentoflavone treatment. The number of cells in the G2 phase after irradiation significantly increased, indicating that the cells that survived radiation injury will switch on the stress response to self-repair, and then will step into the $\mathrm{G} 2$ phase to produce new cells. The treatment of cells with amentoflavone improves this process. The cell group treated with amentoflavone has more cells in the $\mathrm{G} 2$ phase, and under normal nutritional conditions, new cells would be produced from mitosis. A significant decline in the rate of apoptosis was achieved by repairing radiation-induced injury in cells and also by generating new cells.

Overall, based on these results, we have a clear picture of the antioxidant ability of amentoflavone. Future studies can include in-depth investigation of the molecular mechanisms of amentoflavone as a radioprotector in regards to p53, JNK and other signaling pathways and cell cycle regulation.

\section{Acknowledgements}

Thanks to Dan-dan Lu for her technical support and data collection, and to the English teacher Colin (From England).

\section{References}

Bartek J, Lukas J (2001) Pathways governing G1/S transition and their response to DNA damage. Febs Lett, 490, 117-22.

Beecher GR (2003). Overview of dietary flavonoids: Nomenclature, occurrence and intake. J Nutr, 133, 3248-54.

Bernd M, Rainer O (2002). Mitochondrial regulation of apoptosis. News Physiol Sci, 18, 89-94.

Boonstra J, Post JA (2004). Molecular events associated with reactive oxygen species and cell cycle progression in mammalian cells. Gene, 337, 1-13.

Dajas F, Rivera-Megret F, Blasina F, et al (2003). Neuroprotection by flavonoids. Braz J Med Biol Res, 36, 1613-20.

Deng X, Gao F, May WS Jr (2003). Bcl-2 retards G1/S cell cycle transition by regulating intracellular ROS. Hematopoiesis, 102,9 .

Elena B, Valeria N (2004). The Effects of Low Dose Radiation -New Aspects of Radiobiological Research Prompted by the Chernobyl Nuclear Disaster, 1st ed. CRC Press, Boston.

Eric JB, Amit M, Ruth JM (1995). Effects of ionizing radiation on cell cycle progression. Radiat Environ Bioph, 34, 79-83.

Gao F, Yi J, Yuan JQ, Shi GY, Tang XM (2004). The cell cycle related apoptotic susceptibility to arsenic trioxide is associated with the level of reactive oxygen species. Cell Res, 14, 81-5.

Guruvayoorappan C, Kuttan G (2008). Inhibition of tumorspecific angiogenesis by amentoflavone. Biochem (Mosc), 73, 209-18.

Johannes B, Jan AP (2004). Molecular events associated with reactive oxygen species and cell cycle progression in mammalian cells. Gene, 337, 1-13.

Jürgensmeier JM, Xie Z, Deveraux Q, et al (1998). Bax directly induces release of cytochrome $\mathrm{c}$ from isolated mitochondria. Cell Biol, 95, 4997-5002.

Kang DG, Yin MH, OhH, Lee DH, Lee HS (2004). Vasorelaxation by amentoflavone isolated from Selaginella tamariscina. Planta Med, 70, 718-22.

Lee CF, Liu CY, Hsieh RH, Wei YH (2005). Oxidative stressinduced depolymerization of microtubules and alteration of mitochondrial mass in human cells. Ann NY Acad Sci, 1042, 246-54.

Li CR, Zhou Z, Lin RX, et al (2007). $\beta$-sitosterol decreases Irradiation induced thymocyte early damage by regulation of the intracellular redox balance and maintenance of mitochondrial membrane stability. J Cell Biochem, 102, 748-58.

Li CR, Zhou Z, Zhu D, et al (2007). Protective effect of paeoniflorin on irradiation induced cell damage involved in modulation of reactive oxygen species and the mitogenactivated protein kinases. Int J Biochem Cell B, 39, 426-38.

Limoli CL, Giedzinski E, Morgan WF, et al (2003). Persistent oxidative stress in chromosomally unstable cells. Cancer Res, 63, 3107-11.

Lin YM, Anderson H, Flavin MT, et al (1997). In vitro anti-HIV activity of biflavonoids isolated from Rhus succedanea and Garcinia multiflora. J Nat Prod, 60, 884-8.

Linke SP, Clarkin KC, Di Leonardo A, Tsou A, Wahl GM (1996). A reversible, $\mathrm{p} 53$-dependent $\mathrm{G} 0 / \mathrm{G} 1$ cell cycle arrest induced by ribonucleotide depletion in the absence of detectable DNA damage. Gene Dev, 10, 934-47.

Mandel S, Weinreb O, Amit T, Youdim MB (2004). Cell signaling pathways in the neuroprotective actions of the green tea polyphenol epigallocatechin-3-gallate: implications for neurodegenerative diseases. J Neurochem, 88, 1555-69.

Mirjolet JF, Barberi-Heyob M, Didelot C, et al (2000). Bcl-2/Bax protein ratio predicts 5 -fluorouracil sensitivity independently of p53 status. Brit J Cancer, $\mathbf{8 3}, 1380-86$

Mora A, Paya M, Rios JL, Alcaraz MJ (1990). Structure-activity relationships of polymethoxyflavones and other flavonoids as inhibitors of non-enzymic lipid peroxidation. Biochem Pharmacol, 40, 793-7.

Nugent SM, Mothersill CE, Seymour C, et al (2007). Increased mitochondrial mass in cells with functionally compromised Mitochondria after exposure to both direct radiation and bystander factors. Radiat Res, 168, 134-42.

O'Reilly LA, Huang DC, Strasser A (1996). The cell death inhibitor Bcl-2 and its homologues influence control of cell cycle entry. EMBO J, 15, 6979-90.

Rao BS, Shanbhoge R, Upadhya D, et al (2006). Antioxidant anticlastogenic and radioprotectivee effect of Coleus aromaticus on Chinese hamster fibroblast cells exposed to gamma radiation. Mutagen, 21, 237-42.

Reipert S, Berry J, Hughes MF, Hickman JA, Allen TD (1995). Changes of Mitochondrial mass in the hemopoietic stem cell line FDCP-Mix after treatment with etoposide: a correlative study by multiparameter flow cytometry and confocal and electron microscopy. Exp Cell Res, 221, 281-8.

Ross JA, Kasum CM (2002). Dietary flavonoids: Bioavailability, metabolic effects, and safety. Апnи Rev Nutr, 22, 19-34. 
Rosser CJ, Tanaka M, Pisters LL, et al (2004). Adenoviralmediated PTEN transgene expression sensitizes Bcl-2expressing prostate cancer cells to radiation. Cancer Gene Ther, 11, 273-9.

Schmidt-Ullrich RK, Dent P, Grant S, Mikkelsen RB, Valerie K (2000). Signal transduction and Cellular Radiation Responses; Radiat Res, 153, 245-57.

Shimoi K, Masuda S, Shen B, Furugori M, Kinae N (1996). Radioprotective effects of antioxidative plant flavonoids in mice. Mutat Res, 350, 153-61.

Simonyi A, Wang Q, Miller RL, et al (2005). Polyphenols in cerebral ischemia: Novel targets for neuroprotection. Mol Neurobiol, 31, 135-47.

Spodnik JH, Wozniak M, Budzko D, et al (2002). Mechanism of leflunomide-induced proliferation of mitochondria in mammalian cells. Mitochondrion, 2, 163-79.

Sweet S, Singh G (1999). Changes in mitochondrial mass, membrane potential, and cellular adenosine triphosphate content during the cell cycle of human leukemic (HL-60) cells. Journal of Cell Physiol, 180, 91-6.

Vogler M, Weber K, Dinsdale D (2009). Different forms of cell death induced by putative Bcl-2 inhibitors. Cell Death Differ, 16, 1030-9.

Weiss JF, Landauer MR (2003). Protection against ionizing radiation by antioxidant nutrients and phytochemicals. Toxicol, 189, 1-20.

Weiss JF, Landauer MR (2000). Radioprotection by antioxidants. Ann NY Acad Sci, 899, 44-60.

Wu XJ, Kassie F, Mersch-Sundermann V (2005). The role of reactive oxygen species production on diallyl disulfide induced apoptosis and cell cycle arrest in human A549 lung carcinoma cells. Mutat Res, 579, 115-24.

Xu P, Jia JQ, Jia JF, Jiang EJ (2011). Radioprotective effects of troxerutin against gamma irradiation in V79 cells and mice. Asian Pacific J Cancer Prev, 12, 2593-6.

Zhang M, Zhang HQ, Xue SB (2000). Effect of Bcl-2 and caspase- 3 on calcium distribution in apoptosis of HL-60 cells. Cell Res, 10, 213-20.

Zhao B (2005). Natural antioxidants for neurodegenerative diseases. Mol Neurobiol, 31, 283-93. 